\title{
HUHEZIko hiru gradu presentzialen lehenengo mailako ikasleen moodle plataformaren erabileraren azterketa
}

\author{
Iñigo Arriaran Olalde \\ Mondragon Unibertsitatea
}

DOI: $10.1387 /$ tantak.15557

GAKO-HITZAK: Moodle, diseinua, foroa, pertzepzioa, online plataforma.

\section{MOODLE PLATAFORMAREN ERABILERA UNIBERTSITATEAN}

Moodle plataformaren erabileraren inguruan unibertsitateko ikasleen eta irakasleen pertzepzioa jasotzea garrantzitsua bezain beharrezkoa da erabilera hori nolakoa den jakiteko, eta horren arabera beharrezko neurriak hartzeko. Horren inguruan hainbat lan egin dira orain arte, eta hauek dira aipagarrienak: Abdelraheem, 2012; Corbeil eta Valdes-Corbeil, 2013; Costa, Alvelos eta Teixeira, 2012; Elmahadi eta Osman, 2012; Escobar eta Monge, 2012; Islam eta Azad, 2015; López, Romero eta Ropero, 2010; Marín eta Maldonado, 2010; Novo, Varela eta Ramil, 2013; Sánchez Santamaria, Sánchez Antolín eta Ramos, 2012; Wahab, Ali, Thomas eta Al Basri, 2013; Wei Goh, Lang Hong eta Gunawan, 2013.

Álvarez irakasleak (2010) dioenaren arabera, plataforma erabiltzen hainbat urte eman eta gero gomendagarria da horrelako ebaluazioak egitea, etorkizunari begira hobetu beharreko puntuak edo alderdiak aurkitzeko eta, horrela, irakaskuntzaren eskaintzaren kalitate pedagogikoa hobetu ahal izateko.

Azterketa horretan gehiago sakontzea izan da ikerketa honen asmoa. Zehatzago esanda, helburua izan da HUHEZI fakultatean 2013-2014 ikasturtean Haur Hezkuntza, Lehen Hezkuntza eta Ikus-entzunezko Komunikazioa graduetan dauden ikasleen Moodle plataforman egiten duten erabileraren pertzepzioa jasotzea.

Informazio eta komunikazio teknologien (IKT) erabilerak eta onarpenak hezkuntzan oraindik ere ikerketa askoren erronka eta helburu zentrala izaten jarraitzen dute. Nahiz eta egun hezkuntzan IKTek geroz eta funtzio garrantzitsuagoa duten, hainbat sektoreren aldetik (ikasle zein irakasle), al- 
daketen aurreko erresistentzia handiak nabaritzen dira (Xu eta Yu, 2004). IKTak ikaskuntza sisteman integratzeko prozesuan, garrantzi handia dute online bidezko ikasketetan erabiltzen diren euskarriak, konkretuki Ikasteko Ingurune Birtualak (IIB) (Martín eta Serrano, 2009; Romero, Ventura eta García, 2008).

Bestalde, Europako Goi Mailako Hezkuntza Eremuak (EGHE) hezkuntza sisteman rol aldaketak planteatzen ditu. Ikasleak dira beren ikaskuntza prozesuaren protagonista eta irakasleak prozesu horren gidari izatera pasatzen dira (Ciudad, 2010). Eta eremu horretan erabiltzen dira Ikasteko Ingurune Birtualak, ikaskuntza sistema berrian berrikuntza pedagogikoak lortzeko asmoz (Chen, Wang eta Hung, 2009).

Ildo horretatik, Piotrowski-ren (2010) ustez, Ikasteko Ingurune Birtual batek sei aktibitate eskaintzen duen sistema integratu bat da; honako hauek sorkuntza, kudeaketa, entrega, komunikazioa, partaidetza eta ebaluazioa.

Merkatuan plataforma ugari daude: WebCT, Blackboard, TopClasse, Moodle, Ilias, Claroline, e.a. Plataforma horietako batzuk lizentziapekoak dira eta beste batzuk libreak edo software libre erakoak. Guztien artean bi plataforma dira erabilienak, lizentziapeko BlackBoard eta software libreko Moodle (Escobar eta Monge, 2012).

Literaturaren azterketan plataforma-aukeraren inguruko ikerketa ugari aurkitu ditugu, eta bat datoz Moodle plataformaren aldeko hautua egitearen inguruan (Carvalho, Areal eta Silva, 2011; Muhsen, Maaita, Odah eta Nsour, 2013; Novo et al., 2013; Subramanian, Zainuddin, Alatawi, Javabdeh eta Hussin, 2014; Wahab et al., 2013; Wei Goh et al., 2013). Bi arrazoi agertzen dira nagusiki:

a) Plataforma erabiltzea oso erraza dela.

b) Software libreko plataforma bat dela.

Nahiz eta Adell, Castellet eta Gumbauren (2004) ikerketa orain dela 10 urtekoa den, aportazio interesgarriak egiten ditu. Ingurune birtual edo plataforma batzuk aztertu eta gero, arrazoi hauengatik gomendatzen dute Moodle erabiltzea lan horretan:

- Funtzionalitate didaktiko sofistikatuak eta aukera askotakoak eskaintzen ditu. Bere egitura modularretik eratortzen den malgutasunak irakaskuntzako edozein estilori euskarria eman ahal izatea bermatzen du.

- Aukera gehiago ditu (bere izaera modularrak ez du erabilgarritasuna oztopatzen).

- Proiektuaren irekitasun eta dinamismo maila handiagoa ematen du, mundu osoko garatzaileek parte hartzen dutelako, eta horrek plataforma hobetzea ahalbidetzen du, libreki eskuratu daitezkeen moduluen eta ezaugarri osagarrien bitartez. 
Moodle plataformaren zenbakiei erreparatuz gero, 2011. urtean 211 herrialdetan erabiltzen zen plataforma hori, 78 hizkuntzatara itzulita zegoen, 41,5 milioi erabiltzaile zituen (horietako 1,2 milioi tutore edota irakasleak) eta Espainiako unibertsitate publiko eta pribatu ia guztietan erabiltzen zen (Moodle, 2011). Mondragon Unibertsitatean, berriz, 1.742 erabiltzaile ari dira Moodle plataforman lanean gaur egun, eta 1.231 ikastaro sortuta daude (MUko Zerbitzu Teknologiko departamentuaren datuak).

Marín eta Maldonadok (2010), adibidez, Kordobako Unibertsitatean sartu berri ziren ikasleen ezagutza eta jarduera aztertu zuten, eta, aurkitu zutenaren arabera, ikasleek plataforma erabiltzen dutenean zereginetan sartzeko, fitxategiak jasotzeko eta gordetzeko erabiltzen dute batik bat. Sánchez eta Moralesek (2012) berriz, Gaztela-Mantxako Unibertsitateko Moodle plataformaren erabileraren inguruan ikasleek zuten pertzepzioa ikertu zuten. Bertan aurkitu zuten tresnak irakaskuntzaren antolamendua bistaratzea ahalbidetzen zuela, hau da, plataforman diseinatzen den sekuentzia pedagogikoak ikasgaiaren antolaketa hobeto ulertzeko balio zuela.

Lehen aipatu bezala, erabiltzaileen arteko komunikazioa ahalbidetzea da online plataforma bati eskatu beharreko aktibitate edo zerbitzuetako bat. Moodle plataforman komunikazioa ahalbidetzeko baliabide bat foroa da. Aipatzekoa da Islam, Onik eta Azadek (2013, 9 orr.) foroa tresnaren inguruan diotena: «The discussion board is an excellent way to share ideas which could be utilized heavily into the class.» Beste ikerketa batzuk ere bat datoz foroa tresnak komunikaziorako duen ahalmenarekin (Elmahadi eta Osman, 2012; Islam eta Azad, 2015; Wahab et al., 2013).

Baina foroa tresna Moodle plataforman egotea ez da ikasle-ikasle eta ikasle-irakasle komunikazioa ahalbidetzeko baldintza bakarra. Kasu honetan tutore edo irakaslearen papera eta jarrera oso garrantzitsua da tresna hori behar bezala baliatuz plataformako erabiltzaileen artean komunikazioa hobetzeko. Asko dira gai hau aipatzen duten ikerketak (Abdelraheem, 2012; Escobar eta Monge, 2012; Carvalho et al., 2011; Islam eta Azad, 2015; Wahab et al., 2013; Wei Goh et al., 2013). Baina konkretuki bi aipatu nahi ditugu. Islam, Onik eta Azadek, (2013, 9 orr.) hau diote: «Moodle(discussion board) is an excellent tool, but in many cases the lecturers do not know how to use it effectively». Eta gai beraren inguruan baina Moodle plataformara orokortuz, Costa eta lankideek (2012, 342 or.) hau aipatzen dute:

«To overcome the constraints just presented it should be taken into account that the successful use of e-learning platforms in the teaching and learning context critically depends on the teachers having knowledge about the tools, being aware of how they should be used and being capable of organizing all the communication process». 
Plataformaren ahalmena da ikerketetan asko aipatzen den beste gai bat. Plataformari etekin guztia ateratzen diotela uste al dute Moodle plataforma erabiltzen duten ikasleek? Analizatutako ikerketa askok esaten du ezetz, eta konkretuki aipatzen dute plataformari buruzko formazioa jasotzea ez dela nahikoa, irakasleek jarrera aktiboa eta motibagarria erakutsi behar dutela plataformarekiko, ikasleek ere jarrera hori izanda, erabilera positibo eta aktiboa egin dezaten (Abdelraheem, 2012; Carvalho et al., 2011; Escobar eta Monge, 2012; Islam eta Azad, 2015; Wahab et al., 2013; Wei Goh et al., 2013).

Escobar eta Mongeren (2012, 1092 or.) hitzek ondo azaltzen dute gai hau: «Therefore, it is crucial that teachers not simply upload the subject contents on the platform; they should make the effort to impress how useful the Moodle platform and all of its possibilities can be for their learning process».

Konkretuki, ikerketa lan honen helburua galdera hauei erantzutea da:

a) Moodle bidezko ikastaroen diseinuan definitzen den sekuentzia didaktikoak ikasgaien antolamendua hobeto ulertzen laguntzen du?

b) Ikasleekforoa ezagutzen dute? Eta erabiltzen dute?

c) Tutoreek Moodle plataformaren inguruan duten ezagutza eta erabilera maila zenbatekoa da?

Ikerketa hau lagungarria izango da Mondragon Unibertsitateko ikasleek - eta, zehazki, HUHEZI fakultatekoek - Moodle plataformaren inguruan duten pertzepzioa zein den jakiteko, eta lortutako emaitzek erabilera hori hobetu eta bide batez ikaskuntza-irakaskuntza plana hobetzeko balioko dute. Egun, Moodle plataforma unibertsitateko fakultate guztietan erabiltzen den online plataforma da, nola ikasketa presentzialetan, hala online ikasketetan ere.

\section{METODOLOGIA}

Devin eta Clark-en (1987) ustez, datu kuantitatiboak arazoaren magnitudea azalarazten du eta datu kualitatiboak arazoaren zergatiak ulertzen laguntzen. Gure ikerketa-lanaren helburu nagusiekin bat dator ideia hori, bi ikuspuntutik aztertu behar baita ikertzen ari garen kasua, magnitudera hurbildu eta baita zergatiak ezagutu ere. Horregatik, ikasleek Moodle plataformarekin duten esperientzia jasotzeko galdetegia eta eztabaida-taldeen tresnak erabili ditugu, metodologia kuantitatiboa eta kualitatiboa uztartuz.

\section{Parte-hartzaileak}

Ikerketa aurrera eramateko HUHEZIko hiru graduetako ikasleak aukeratu ziren. Zehazki, 2013-2014 ikasturtean hasitako ikasle berriak : Haur 
Hezkuntza, Lehen Hezkuntza eta Ikus-Entzunezkoen Komunikazioa graduetako ikasleak.

Guztira 175 ikaslek hartu zuen parte ikerketan, lehen mailakoak, modalitate presentzialean ikasten ari diren Lehen Hezkuntzako (LH) 90 ikasle, Haur Hezkuntzako (HH) 46 ikasle eta Ikus-Entzunezko Komunikazioa (IKO) Graduko 39 ikasle. (ikus 1. grafikoa).

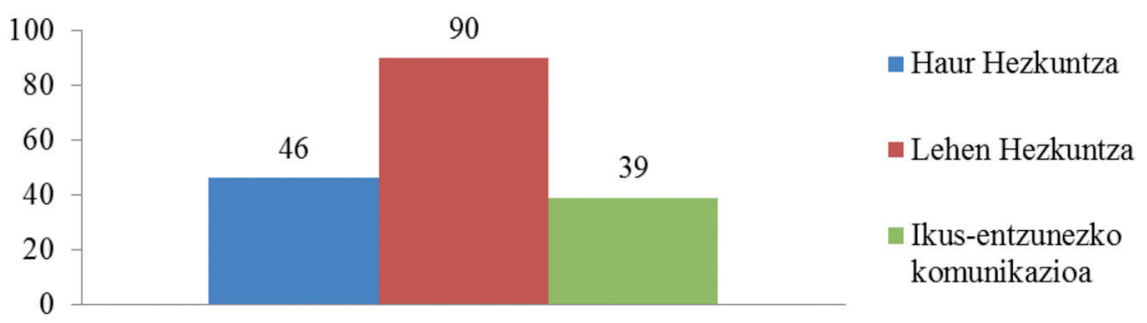

1. grafikoa

Ikasle kopurua gradu bakoitzean

Ikasle horien adina 18-27 bitartekoa da eta emakumezkoak gizonezkoak baino gehiago ziren, 103 emakume eta 72 gizonezko hain zuzen ere (ikus 2. grafikoa).

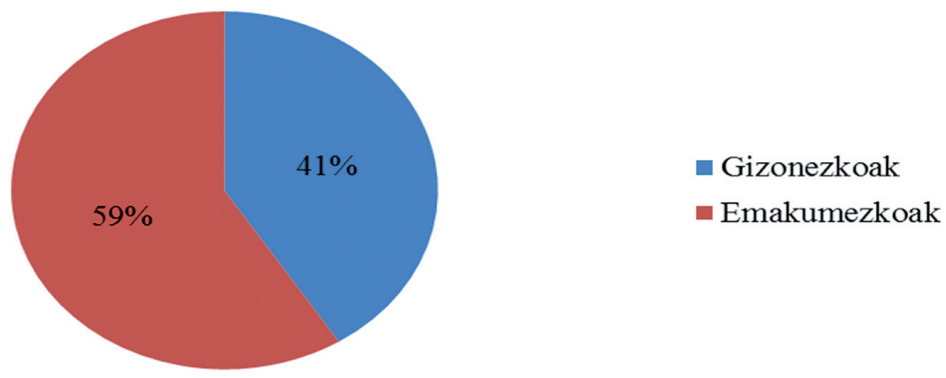

2. grafikoa:

Sexua

Ikasle horiek galdetegia bete eta eztabaida-taldean parte hartu baino lehenago, 10 hilabetez erabili zuten HUHEZI fakultateko Moodle plataforma. 


\section{Tresnak}

Ikerketa hau aurrera eramateko bi motatako tresnak erabili dira. Galdetegia alderdi kualitatiboa analizatzeko, eta eztabaida-taldea alderdi kualitatiboa analizatzeko.

Galdetegia garatu eta moldatzerakoan prozesu hau jarraitu da (Grau, 1995; Martín Arribas, 2004):

1. Konstruktuaren definizioa osatu. Lehenengo eta behin, neurtu nahi dena zehaztu da. Lan hori ikerketa bibliografikoaren bidez eta adituei kontsultatuz egin da.

2. Jarraian, galdetegiaren hainbat gai zehaztu dira: edukia, populazio hartzailea eta izango duen formatua.

3. Itemak sortu eta erantzunen aukerak zehaztu dira, Hor ikerketa bibliografikotik eskuratutako tresnen bidez, eta adituak kontsultatuz.

4. Balioztatze-prozesua. Galdetegia ulerkorra eta baliagarria dela egiaztatu da.

Galdetegia sortzeko prozesuan, lehenengoz horrelako tresnarik dagoeneko baote den aztertu da bibliografian. Egindako bilaketan hainbat galdetegi aurkitu ditugu: Carvalho et al., (2011); Correa (2005); Lopez et al., (2010); Marin eta Maldonado (2010); Sánchez eta Morales (2012); Wahab et al., (2013); Wei Goh et al., (2013). Hala ere, ez dugu galdetegi egoki bat aurkitu, errebisatu ditugun galdetegiak partzialak dira, beste kultura eta hizkuntza batzuetan eginak. Horregatik erabaki da ikerketa honetarako galdetegi propioa garatzea, aurretik kontsultatu diren beste galdetegiak kontuan hartuta.

Galdetegiko ataza-itemak diseinatzerakoan, bereziki ikerketa lan honetan erabilitako galdetegia izan dugu kontuan: Usos pedagógicos de Moodle en la docencia universitaria desde la perspectiva de los estudiantes (Sánchez Santamaría et al., 2012).

Galdetegiaren lehenengo bertsioa osatu eta gero, gaiaren inguruko hiru adituk balioztatu dute, Mondragon Unibertsitateko Online ikasketen koordinatzailea, MUko Online ikasketen talde akademikoaren koordinatzaile teknikoa eta MUko Komunikazioa guneko Doktore eta Hezikom ikerketataldeko kide bat.

Hiru adituen proposamenekin, galdetegiaren bigarren bertsioa osatu da. Galdetegiaren balioztatzearekin bukatzeko MUko beste bi fakultateetako 6 ikaslerekin aztertu da galdetegia, haren itemen ulermena balioztatzeko. Ikasleen proposamenak aztertu ondoren, egin beharreko aldaketak egin dira eta galdetegiaren azken bertsioa osatu da.

Galdetegiaren azken bertsioa 12 itemez osatuta dago.

Alderdi kualitatiboa aztertzeko Eztabaida Taldea tresna erabili da. Galdetegian izandako emaitzak konfrontatzeko eta ikasleen iritzi kualitatiboak jasotzeko, ikasleekin osatutako eztabaida talde bat osatu dugu, hiru gra- 
duetako ikaslez osatutako taldea (gradu bakoitzeko bi ikasle aukeratu dira, guztira 6 pertsona).

Kategoria tematikoak sortzerakoan ikerketako hiru helburuak izan dira kontuan: Moodle plataformak - eta konkretuki bertan jarritako edukiekikasgai edo materiaren antolaketa hobeto ulertzeko balio duten, plataformakoforoa zenbatetaraino eta zertarako erabiltzen den, eta tutoreek Moodle plataformaren inguruan duten ezagutza eta erabilera maila zenbatekoa den.

Hiru gai tematiko horiez gain, eztabaida taldea Moodle plataformaren inguruko iritzi orokorrak jasotzeko ere aprobetxatu da.

\section{Prozedura}

Ikerketa hau hiru fasetan bideratu da. Lehenik eta behin, HUHEZIko Graduetako koordinatzaileari aurkeztu zitzaion proiektua, ikerketaren nondik norakoak azaltzeko.

Behin fakultatearen parte-hartzea baieztatu ondoren, ikerketan parte hartuko zuten ikasleei azaldu zitzaien proiektua, eta beraien parte-hartzea eskatu zen, beti ere, ikasle bakoitzaren anonimotasuna bermatuko zela ziurtatuz. Ikasleen parte-hartzea lortu eta gero, kronograma bat bateratu genuen, datuen bilketa aurrera eramateko.

Datuen bilketa galdetegia eta eztabaida taldea tresnen bidez egin zen. Galdetegia 2014ko uztailean pasatu zitzaien ikasleei, eta 2015eko urtarrila bitartean egin zen datuen analisia. Galdetegia egun berean pasatu zitzaien hiru talde edo graduetako ikasleei. Presentzialki eta eskuz bete zuten galdetegia ikasleek.

Galdetegiko datuen analisia egiteko SPSS 17.0 eta Microsoft Excel 2010 programak erabili dira.

Eztabaida taldea 2015eko urtarrilean egin zen fakultateko gela batean. Eztabaida audio grabatzaile batekin grabatu zen, ondoren transkripzioa egin ahal izateko.

\section{EMAITZAK}

Alde batetik galdetegiaren emaitzak erakutsiko dira. 12 item-en emaitzak emango dira, banaka.

Eztabaida taldeko emaitzak erakutsiko dira ondoren, ikasleek aipatutako adierazpen esanguratsuenak analizatuz.

\section{Galdetegiaren emaitzak}

Ikerketa lana prestatzean galdetegiaren emaitzak lagina osatzen duten hiru graduetako (Lehen Hezkuntza, Haur Hezkuntza eta Ikus-entzunezko 
Komunikazioa) ikasleak ez bereiztea aurreikusi da; ikasleei zuzendutako galderak kontuan izanda, ez da emaitza-desberdintasun handirik atera. Gradu bakoitzeko emaitzak atera ondoren, aurreikuspena baieztatu da, lorturiko emaitzak oso antzekoak izan baitira.

Ikaslearen baieztapena jasotzerako orduan, Gutxi terminoa hartu daiteke kontuan edo 1 balioa. Ikerketa lan honetan zenbakiak hartu dira kontuan emaitzak emateko, eta 0-4 eskala erabili da (ikus 1. taula).

1. taula

\begin{tabular}{ll}
\hline EZER EZ & 0 \\
GUTXI & 1 \\
BATZUETAN & 2 \\
ASKOTAN & 3 \\
BETI & 4 \\
\hline
\end{tabular}

Galdera: Plataforman definitzen den sekuentziak materiaren antolaketa ulertzeko balio du?

Plataforman definitzen den sekuentziak plataforman edukiak jartzeko jarraitzen den ordena esan nahi du. Eta galderaren bitartez jakin nahi da ea ordena edo sekuentzia horrek materian erabiltzen den antolaketa hobeto ulertzeko balio duen ala ez.

Emaitzak analizatzerakoan, 2. taulan ikusten den bezala, plataforman definitzen den sekuentzia materiaren antolaketa ulertzeko balio du ikasleen gehiengoarentzat. 3 zenbakiarekin ikasleen $\% 53$,1ek baloratu dute eta 4 zenbakiarekin \% 11,4k. Aipatzekoa da, hala ere, 2 zenbakiarekin baloratu duten ikasle kopurua nahiko altua dela $(\% 31,4)$.

\section{2. taula}

Plataforman definitzen den sekuentzia didaktikoa materiaren antolaketa ulertzeko balio du?

\begin{tabular}{ccccc}
\hline 0 & 1 & 2 & 3 & 4 \\
$\% 0,6$ & $\% 3,4$ & $\% 31,4$ & $\% 53,1$ & $\% 11,4$ \\
\hline
\end{tabular}

Lagineko ikasle guztien emaitzak kontuan izanda, item honetan lortutako batez bestekoa $\mathbf{2 , 7 k o a ~ i z a n ~ d a . ~}$ 
Galdera: Ikastaroko edukiak hierarkizatzeko letra mota edo tamaina desberdinak erabiltzen dira?

Kasu honetan emaitzak hauek dira: 2 zenbakia aukeratu dute ikasle gehienek $(\% 43,4)$ eta 3 zenbakia jarraian (\% 33,7). 3 eta 4 zenbakia aukeratu dutenak batuz, ikasle gehienek uste du plataforman edukiak hierarkizatzeko letra mota edo tamaina desberdinak erabiltzen direla ikastaroak diseinatzerakoan. Hala ere, oso kontuan izan behar da 2 zenbakia erantzun duten ikasle kopurua oso altua dela $(\% 43,4)$. Guzti hau 3. taulan ikusi daiteke.

3. taula

Ikastaroko edukiak hierarkizatzeko letra mota edo tamaina desberdinak erabiltzen dira?

\begin{tabular}{ccccc}
\hline 0 & 1 & 2 & 3 & 4 \\
$\% 4,6$ & $\% 8$ & $\% 43,4$ & $\% 33,7$ & $\% 10,3$ \\
\hline
\end{tabular}

Lagineko ikasle guztien emaitzak kontuan izanda, item honetan lortutako batez bestekoa $\mathbf{2 , 4 k o a ~ i z a n ~ d a . ~}$

Galdera: Plataforman eman diren mezuak argiak izan dira?

4. taula

Plataforman eman diren mezuak argiak izan dira?

\begin{tabular}{ccccc}
\hline 0 & 1 & 2 & 3 & 4 \\
$\% 1,7$ & $\% 13,7$ & $\% 37,7$ & $\% 42,9$ & $\% 4$ \\
\hline
\end{tabular}

Aurreko galderetako bide bera hartzen dute item honetako erantzunen emaitzak: 3 zenbakikoa da ikasle gehienek aukeratu duten erantzuna (\% $42,9)$, baina erantzun kopuru handia dauka baita ere 2 zenbakiak $(\% 37,7)$. Beste erantzun posibleen emaitzak oso baxuak dira, 1 zenbakiarenak izan ezik. Ikasleen \% 13,7ak (25 ikasle gutxi gora behera) oso balorazio baxua eman dio galdera honi.

Galdetegiko item honetan lortutako batez bestekoa 2,3koa izan da. 
Galdera: Egitekoak edo zereginak argi eta ondo azalduta egon dira plataforman?

Nahiz eta 2 zenbakia erantzun duten ikasleen kopurua altua izan (\% 31,4), 3 edo 4 zenbakia erantzun dutenak gehiago dira, $\%$ 50,3 eta $\% 13,1$ hurrenez hurren. Esan daiteke, beraz, ikasle gehienek uste dutela plataforman planteatzen diren egiteko edo zereginak, oro har, argi eta ondo ulertzen direla.

\section{5. taula}

Egitekoak edo zereginak argi eta ondo azalduta egon dira plataforman?

\begin{tabular}{ccccc}
\hline 0 & 1 & 2 & 3 & 4 \\
$\% 0$ & $\% 5,1$ & $\% 31,4$ & $\% 50,3$ & $\% 13,1$ \\
\hline
\end{tabular}

Lagineko ikasle guztien emaitzak kontuan izanda, item honetan lortutako batez bestekoa $2,7 \mathrm{koa}$ izan da.

Galdera: Ikasleei informazio gehigarria eskaintzeko 2.0 baliabideak (bideoak, aurkezpenak, ...) erabiltzen dira?

Kasu honetan laginaren \% 64,3k (112 ikaslek) erantzun positiboa eman dute, 3 edo 4 zenbakia aukeratuz. Eta ikasle oso gutxik uste dute plataforman 2.0 baliabideak ez direla erabiltzen $(\% 7,4 \mathrm{k})$. Aipatzekoa da, baita ere, 3 zenbakia aukeratu dutela ikasle gehienek, ia laginaren erdiak (\% 48k).

\section{6. taula}

Ikasleei informazio gehigarria eskaintzeko 2.0 baliabideak erabiltzen dira?

\begin{tabular}{ccccc}
\hline 0 & 1 & 2 & 3 & 4 \\
$\% 1,1$ & $\% 6,3$ & $\% 26,3$ & $\% 48$ & $\% 18,3$ \\
\hline
\end{tabular}

Item honetan lortutako batez bestekoa 2,8 koa izan da.

Galdera: Plataformako Foroa erabiltzen da ikasgaiaren gaiak eztabaidatu, gauzak partekatzeko, zalantzak argitzeko...?

Galdera honetan plataformakoforoaren erabileraren inguruan galdetu zaie ikasleei.

Erantzunak oso argiak dira. Ikasle gehienek foroa Moodle plataforman ez duela erabiltzen adierazten du. 0 zenbakia aukeratu dute ikasleen 
$\%$ 43,4k. Beraz lagineko ia 76 ikaslek (175etik)foroa inoiz ez duela erabili adierazten du. Bestalde, erantzun positiboa eman duten ikasleen portzentaia txikia da, \% 13,2koa besterik ez.

7. taula

Plataformako Foroa erabiltzen da ikasgaiaren gaiak eztabaidatu, zalantzak argitzeko,...?

\begin{tabular}{ccccc}
\hline 0 & 1 & 2 & 3 & 4 \\
$\% 43,4$ & $\% 18,3$ & $\% 25,1$ & $\% 10,9$ & $\% 2,3$ \\
\hline
\end{tabular}

Lagineko ikasle guztien emaitzak kontuan izanda, item honetan lortutako batez bestekoa 1,1ekoa izan da.

Galdera: Oro har, tutoreek Moodle plataformaren inguruan duten ezagutza eta erabilera maila zenbatekoa dela uste duzu?

Kasu honetan emaitzak hauek dira: 2 zenbakia aukeratu dute ikasle gehienek (\% 48,6k) eta 3 zenbakia jarraian (\% 37,7). Beste zenbakiak $(0,1$ eta 4) aukeratu duten ikasle-kopuruak oso txikiak izan dira, 8. taulan ikusi daitekeen bezala. Hala ere, oso kontuan izan behar da 2 zenbakia erantzun duten ikasle kopurua oso altua dela (\% 48,6).

8. taula

Oro har, tutoreek plataformaren inguruan duten ezagutza eta erabilera maila zenbatekoa dela uste duzu?

\begin{tabular}{ccccc}
\hline 0 & 1 & 2 & 3 & 4 \\
$\% 0$ & $\% 12$ & $\% 48,6$ & $\% 37,7$ & $\% 1,7$ \\
\hline
\end{tabular}

Lagineko ikasle guztien emaitzak kontuan izanda, item honetan lortutako batez bestekoa $\mathbf{2 , 3 k o a ~ i z a n ~ d a . ~}$

Galdera: Oro har, nola antzematen duzu Moodle plataformaren erabilera landu dituzun materietan?

Moodle plataformaren inguruko iritzia zein den ikasleei galdetzerakoan, nahiko argi erantzun dute. Ikasle gehienak oso edo guztiz ados daude Moodle plataformarekin. Aipatzekoa da ikasleen erdiak baino gehiagok 3 zenbakiarekin baloratu duela item hau, eta ia \% 20k balorazio gorenare- 
kin, 4 zenbakiarekin alegia. Balorazio baxuak erantzun-kopuru oso txikiak izan dituzte, 9. taulan ikusi daitekeen bezala.

$$
\text { 9. taula }
$$

Oro har, nola antzematen duzu plataformaren erabilera landu dituzun materietan?

\begin{tabular}{ccccc}
\hline 0 & 1 & 2 & 3 & 4 \\
$\% 0,6$ & $\% 3,4$ & $\% 22,9$ & $\% 54,9$ & $\% 18,3$ \\
\hline
\end{tabular}

Lagineko ikasle guztien emaitzak kontuan izanda, item honetan lortutako batez bestekoa $\mathbf{2 , 9 k o a ~ i z a n ~ d a . ~}$

\section{Eztabaida taldeko emaitzak}

Eztabaida taldean parte hartu duten ikasle guztiek uste dute materiaren edukiak Moodle plataforman egoteak erraztu egiten duela eguneroko lana. Aipatzen dute, baita ere, plataformak asko laguntzen diela materian galduta daudenean bide zuzena bilatzeko, adibidez: gaixorik egonez gero klasean eman dena begiratzeko, materian galduta egonez gero oso lagungarria dela oreka berreskuratzeko eta zeregin edo ariketen entregatze datak kontsultatu eta errespetatzeko. Honela dio Haur Hezkuntza graduko ikasle batek (HH1) «Materia bakoitzean ematen diren edukiak bertan daude ordenatuta eta nahi dotenian eskura. Azkenera plataformako edukia gida bat da: zer eman duzun, noiz eman duzun, erabili den materiala...»

Taldeko kide guztiak ados daude plataformaren inguruko beste alderdi hauekin: plataforman lan egitea erraza da, oso azkarra da bertan lan egitea, eta material guztia eskura dago.

Horretaz gain, plataforman materiek duten antolaketaren inguruan galdetu zaie, hau da, tutoreek materia antolatzerako orduan hasieran zehaztutako sekuentzia didaktikoa jarraitzen duten ala ez.

Lehen Hezkuntza graduko ikaslea (LH2) - «Zeregin batzuetan klasean aipatu dan entregatze data eta plataforman jarri dena ez da berdina izan. Honek asko liatzen du».

Ikus-entzunezko komunikazio graduko ikaslea (IKO1) - «Materia batzuetan irakasleek ez dituzte edukiak ondo antolatzen. Kasu hauetan plataforma lagungarri baino gehiago liatzen gaitu».

(HH2) - «Plataforman edukien blokeak ondo diseinatzea eta mota eta tamaina desberdinetako letrak erabiltzea oso inportantea da. Bestela oso galduta egoten zara». 
Taldeak beste gai bat ere aipatu du, graduan zehar egiten dituzten lan guztien txoko bat sortzea ondo legokeela proposatu dute, hau da, plataforman leku pertsonal bat izatea bertara igo dituzten lan guztiekin. Horrela, lanak beti eskura egongo lituzkete titulazio guztian zehar.

2.0 baliabideen inguruan ikasleek uste dute praktika ona dela irakasleek plataformako edukietan baliabide horiek txertatzea. Oso gustuko dituzte bideoak eta argazkiak. Bideoen kasuan luzera handia bada edo hitzaldiren bat jasotzen badu, oso aspergarria dela esaten dute.

(LH1) - «Bideoak interesgarriak? Segun zein bideo. Hitzaldi batekoa bada, oso aspergarria da.»

Eta beste batek hau dio (HH2): «2.0 baliabide guztiak ez dira gehigarriak materiarako. Askotan hobeto da gauza berdina irakasleak gelan azaltzea bideoan ikustea baino.» Ikasleentzat ikus-entzunezkoa «ikus-entzunezko» izate hutsagatik ez da ona eta positiboa ikaste prozesurako. Baliabide horren erabilera nolakoa den garrantzitsua da ikasleen ustetan.

Gai horren inguruan ia ikasle guztiek azken gai haut aipatu dute: «Batzuetan eduki hori plataforman egotea ez da onena. Irakasleak aurkezpen bat jartzen badu gelan, eta plataforman dagoela esaten badizu, ez duzu hainbesteko atentzioa jartzen eta ez duzu denbora larregi aprobetxatzen. Erlaxatu egiten zara.»

Plataformako Zereginak tresnaren inguruan, taldeko kide gehienek uste dute zereginetan ematen diren azalpenak argiak eta ondo emanak direla. Elementu negatiboen artean, ikasle batek aipatu du batzuetan zereginak bilatzeko arazoak dituela, beste eduki batzuekin batera agertzen delako nahastuta. Hori saihesteko, plataforman bilatzaile bat jartzea ondo legokeela esan du. Eztabaida taldeko moderatzaileak esan dio tresna hori plataforman badagoela eta, egun, materietan txertatuta dagoela. Ikasleak erantzun du inork ez diola tresna hori dagoela azaldu. Taldeko beste ikasle guztiak ados daude egiaztapen horrekin.

Jarraian galdera hau egin diegu ikasleei: plataforman ematen diren mezu eta zereginetan ulertzeko arazoak izaten duzuenean, zein prozedura jarraitzen duzue zalantzak argitzeko? Ikasle guztiak ados egon dira aipatu den prozedurarekin: «lehenengo beste ikaskideei galdetzen diegu (korreoz, mugikorraren bidez edo zuzenean), bestela tutoreari mezu elektroniko bat bidaltzen diogu, baina plataformatik kanpo, fakultateko korreo elektronikotik eta oraindik zalantza ez badugu argitu klase presentzialean tutoreari zuzenean galdetzen diogu.»

Taldeko ikasle guztiek esaten dute inoiz ez dutela plataforma erabili izandako zalantza bat argitzeko.

Mezuen gaiarekin jarraituz, beste bi ikasleen iritziak aipatuko ditugu:

(IKO1) - «Foroa, Txat-a eta horrelako tresnak ez dot inoiz erabili. Baina hori ez dizkigutelako azaldu eh? Bestela nik erabiliko nituzke. Neri bakarrik azaldu didate edukien inguruko gauzak, nola hartu eta nola igo edukiak. Besterik ez didate azaldu». 
(HH1) - «Nik beti eduki dot sentsazioa Moodle ez dugula aprobetxetan, eta ez dotzagula ataraten atara leiken etekin dana. Gauza oso sinpleetarako erabiltzen dogula, gauza oso erabilgarrixak baina sota, caballo, rey. Hortik ez garela pasetan».

Moodle plataformakoforoaren inguruan, ezagutzen dutela esan dute taldeko ikasle guztiak. Hala ere, nahiz eta denek ezagutu inork ez duela erabiltzen esan dute baita ere.

«Nik aurretik banekien foro bat zer zan, baina ez nekien Moodle-en foro tresna zegoela. Galdetegia betetzerakoan enteratu nintzen foro bat zegoela, eta grazia egin zidan, argi neukalako klaseko inork ez zekiela Moodle-en foro bat zegoela».

Ez erabiltzearen arrazoiak aipatzerakoan, arrazoi desberdinak eman dituzte. Oro har, uste dute ez dietela behar bezala azaldu tresna horren funtsa. Lehenengo mailako formazio tailerrean aipatu zitzaiela esan du ikasle batek, baina gero materietan ez dutela inolako azalpenik jaso. Bestalde, irakasleek ere ez diotela inportantziarik ematen aipatu dute, ez baitute materietan ezertarako erabiltzen.

Oso inportantea ikusten dute materia barruan Foroak duen funtzioa ondo azaltzea materia hastean, eta gero irakasle eta tutoreek berorren erabilera bultzatzea. «Irakasleek abisuak ez dituzte forotik komunikatzen, korreo bat bidaltzen dute eta listo. Lehenengo irakasleak bultzatu beharko du erabilera gero gu erabiltzen hasteko.»

Ikasle baten adierazpen orokor honekin bukatzen da eztabaida taldea:

(LH2) - «Eztabaidan aritu garen atal edo galdera guztien erantzuna ixa berdina da: guk plataforma erabiltzen dugula gauzak igotzeko eta hartzeko. Hori bakarrik. Beste ezebe!!»

\section{ONDORIOAK}

1. ondorioa: Plataforman definitzen den sekuentzia didaktikoak materia hobeto ulertzeko balio du.

Ikasle gehienek uste dute plataforman definitzen den sekuentzia didaktikoak materiaren antolaketa hobeto ulertzeko balio duela. Adierazpen hori bat dator Muñoz, Ortiz eta González-ek (2010) adierazitako emaitzekin. Kasu hartan, plataforman definitzen den sekuentzia didaktikoak ikasgaia hobeto ulertzeko balio izatea izan zen kalifikazio altuena lortutako adierazlea. Hantzeko emaitzak eta iritziak lortu dira beste ikerketa batzuetan ere (Carvalho et al., 2011; Wahab et al., 2013; Wei Goh et al., 2013).

Antzeko ebidentziak eskuratu dira eztabaida taldean jasotako iritzietan. Ikasleek uste dute Moodle plataformak gida funtzioa betetzen duela kasu askotan (gaixo, medikua, beste azterketa bat, e.a.), eta materiaren ordena berreskuratzeko balio duela. Tutoreak diseinatzen dituen blokeak ondo 
eta argi egotea oso garrantzitsua dela uste dute. Horrela egiten ez bada, kontrako helburua lortzen baita, gehiago galtzea hain zuzen ere. Gómez, Hernández eta Rico (2009) eta Grace Jun eta Lee-ren (2012) ildotik, horrek agerian uzten du plataforman definitzen den sekuentzia didaktikoak ikaslea materian gidatzeko balio duela, baina baita definizio hori gaizki egiten bada ikaslea samurrago galtzea eragin dezakeela. Ildo beretik, eta Correak (2005) dioen bezala, Moodle plataforman oso samurra da ikasgaiaren sekuentzia didaktikoa behar bezala definitzea.

Bestalde, ikasle askoren ustetan, irakasleek gutxitan erabiltzen dituzte letra mota eta tamaina desberdinak ikastaroko edukiak hierarkizatzeko. Gai horren inguruan ez dago aipamenik errebisatutako literaturan.

2. ondorioa: Plataforman diseinatutako materietan irakasleek askotan erabiltzen dute material gehigarria.

Plataforman diseinatutako materietan irakasleek askotan erabiltzen dute material gehigarria (bideoak, komikiak, aurkezpenak, audioak, e.a.). Moodle plataforman, berezko tresnez gain, samur txertatu eta erabili daitezke beste era bateko tresnak edo materialak (Álvarez, 2010). Are gehiago, gomendagarria da ikasleen motibazioa eta interesa pizteko baliabide horiek ikastaroen edukietan txertatzea (Álvarez, 2010; Costa et al., 2012; Nikodijevic, Kuzmanovic eta Andelkovic, 2014; Ornat eta Kallas, 2012). Antzeko ebidentziak eskuratu dira eztabaida taldean jaso diren iritzietan. Ikasle guztiek adierazi dute tutoreek baliabide gehigarriak erabiltzen dituztela beraien ikasgaien edukietan informazio gehigarria eskaintzeko.

Hala ere, eztabaida taldeetan beste gai bat ere aipatu da, aurrekoa baino adierazgarriagoa. Ikasleen ustetan, plataforman erabiltzen diren baliabide guztiak ez dira berdinak. Beraien esanetan edozein ikus-entzunezko ez da baliagarria. Bideoak eta argazki-irudiak oso gustuko materialak direla aipatu dute, baina aurkezpenak eta Interneteko loturak, aldiz, ez hainbeste. Bideoen artean ere desberdintasunak daudela aipatu dute. Esaterako, bideoa oso luzea bada, edota hitzaldi bat bada, oso aspergarria egiten dela adierazi dute. Aztertu den literaturan azken gaiaren inguruan ebidentziak aurkitu dira. Muñoz eta lankideen lanean (2009), plataforman diseinatzen diren edukien kalitate pedagogikoa neurtzeko adierazleen artean, kalifikazio gutxien lortu zuten bi adierazleak baliabide didaktikoak eta baliabideen kalitatearen inguruko adierazleak izan ziren. Ildo beretik doaz beste ikerketa lan batzuetako emaitzak ere, hau da, oso erabilgarriak direla era horretako materialak plataforman txertatzea, baina ez edozein material (Costa et al., 2012; Nikodijevic et al., 2014; Wahab et al., 2013).

3. ondorioa: Moodlen dauden baliabideak gelan presentzialki erabiltzerakoan ikasleen atentzioa jaitsi egiten da.

Moodlen dauden baliabideak gelan presentzialki erabiltzerakoan, ikasleen atentzioa jaitsi egiten dela aipatu dute ikasle guztiek eztabaida taldean. 
Ikasleek uste dute kasu gehienetan, plataforman eskaintzen den informazio gehigarria (aurkezpenak, bideoak, Interneteko loturak, irudiak, e.a.) gelan ere ikusi edo azaltzean, ikaslearen atentzioa jaitsi egiten duela. Ondorio hori ezin izan da galdetegiko erantzunekin kontrastatu, galdetegian horren inguruko galderarik ez zegoelako, literaturan eta errebisatutako beste galdetegietan ezer aipatzen ez baitzen.

4. Ondorioa: Plataforman jarritako zereginak argi eta ondo azalduta egoten dira.

Ikasle gehienek uste dute plataforman jarritako zereginak argi eta ondo azalduta daudela.

Zereginen tresna Moodle plataforman gehien erabiltzen direnen artean dago, hainbat ikerketa lanetan adierazten den bezala (Correa, 2005; Cosano, 2013; Gomez et al., 2009; Iglesias, Olmos, Torrecilla eta Mena, 2014; López et al., 2010; Marín eta Maldonado, 2010; Maz, Bracho, Jiménez eta Adamuz, 2013). Sánchez Santamaría eta lankideek (2012) aipatzen dute baita, dokumentuak plataformara igotzea, zereginen bidalketa eta plataformako mezularitza direla ikasleek gehien erabiltzen dituzten tresnak. Hala ere, ikasleen ustetan zereginen bidalketa da tresnen artean erabiliena.

Aztertutako literaturan berriz, ez da gai horren inguruko ebidentziarik aurkitu. Hainbat ikerlarik zeregina aipatzen dute tresnaren inguruan, baina ez zeregin horiek argi eta ondo azalduta dauden ala ez.

Eztabaida taldeetan jasotako ebidentzietan ere emaitza berdinak lortu dira. Hala ere, ikasle batek aipatu du arazoak izaten dituela ikasgai edo materia batzuetan zereginak bilatzeko orduan, eta plataforman bilatzaile bat izatea oso erabilgarria izango litzatekeela gehitu.

5. ondorioa: Plataformaren inguruko zalantzak argitzeko ez dute plataforma erabiltzen.

Eztabaida taldean ikasleak konturatzen dira gauza garrantzitsu batez; hots, plataforman zalantzaren bat izaten dutenean (zereginen bat ez bada ulertzen, zereginaren data gaizki jarrita badago, edukiren bat oker igo badu tutoreak, ...) ez dutela plataforma erabiltzen zalantza hori argitzeko. Agerikoa da baita prozedura berbera jarraitzen dutela askotan: lehenengo ikaskideei galdetzen diete (korreoz, mugikorraren bidez edo zuzenean), bestela tutoreari mezu elektroniko bat bidaltzen diote, baina plataformatik kanpo, fakultateko korreo elektronikotik, eta oraindik zalantza ez badute argitzen, klase presentzialean tutoreari zuzenean galdetzen diote.

Hau ez dator erabat literaturan aztertu diren lanetan aipatzen denarekin. Plataformak eta, konkretuki, mezuak bidaltzeko tresna, ikasle-irakasle eta ikasle-ikasle komunikazioa laguntzeko oso baliogarria dela eta ikaste prozesuan ikasleei asko laguntzen diela aipatzen da hainbat lanetan (Correa, 2005; Cosano, 2013; Elmahadi eta Osman, 2012; Iglesias et al., 2014; Islam eta Azad, 2015; López et al., 2010; Maz et al., 2013; Wahab et al., 2013). 
6. ondorioa: Ikasleek foroa tresna ezagutzen dute baina ez dute erabiltzen.

Ikasleek ezagutzen dute Moodle plataformako foroa, baina gehienek ez dute erabiltzen. Benetan aipatzekoa da galdetegia bete duten ikasleen ia erdiak ez duela foroa inoiz erabili. Antzeko ebidentziak azaleratu dira eztabaida taldean jaso diren iritzietan. Beste ikerketa batzuetan ondorioztatutakoa ez dago sintonian gure ikerketan izan diren emaitzekin. Zehazki Moodle plataformako foroa aztertzen duen lan batean, esaterako, foroaren erabileraren inguruan aipatzen dute foroak lagundu egiten duela ikasleikasle eta ikasle-irakasle komunikazioa hobetzen. Hierarkia aldaketak samurtzen ahalbideratzen du foroa erabiltzeak, erlazio horizontalagoa lortuz (Maz, Bracho, Jimenez eta Adamuz, 2013).

Aipatzekoa da, beraz, ikerketa lan honetarako kontsultatu diren beste ikerketa lanetan ez dela guk jasotako moduko ondoriorik jaso. Are gehiago, foroa tresna oso ondo baloratua eta oso erabilia da, gehienbat plataformako edota edukien zalantzak galdetzeko (Islam eta Azad, 2015). Moodle plataformako tresnen balorazio-emaitzetan ere, gure emaitzekin kontrastatuz, foroa balorazio gehien jasotzen duten tresnen artean kokatzen da (Correa, 2005; Elmahadi eta Osman, 2012; Gómez et al., 2009; Islam, Onik eta Azad, 2013; Lopez et al., 2010; Marin eta Maldonado, 2010; Wahab et al., 2013).

Eztabaida taldean tresna hau ez erabiltzearen arrazoiak aipatzerakoan, ikasleek arrazoi desberdinak eman dituzte. Oro har uste dute ez dietela behar bezala azaldu tresna eta irakasleek ez diotela inportantziarik ematen, ez baitute beraien materietan ezertarako erabiltzen. Beraz, eta eztabaida taldean emandako iritziak kontuan izanda, agerikoa da ikasleek formazio beharra dutela tresna honetan. Baina kontuan izan behar da baita tresna honen erabileraren inguruko irakasleen exijentzia maila handitu egin behar dela. Horrela, irakasleak ez badu espresuki foroen erabilera bere materian bultzatzen, ikasleak ondo formatuta egonda ere, egoera ez da aldatuko.

Kontsultatutako ikerlan askotan adierazten da irakasleak izan behar direla tresna hauen erabilera pizteko bideratzaile eta prozesuaren motorrak, eta bide batez, komeni dela ikasleei argitzea zein irizpideren arabera erabiliko den tresna. Beraz, ikasleek teorian ezagutuko dituzte foroak, baina sistematikoki erabili ahal dezaten, irakasleak bideratu egin behar ditu ikasleak (Carvalho et al., 2011; Escobar eta Monge, 2012; Islam eta Azad, 2015; Islam, Onik eta Azad, 2013; Wahab et al., 2013; Wei Goh et al., 2013).

7. ondorioa: Tutoreek Moodle plataformaren inguruan duten ezagutzaeta erabilera-maila altua da.

Galdetegiko emaitzen arabera, ikasle gehienek uste dute tutoreek Moodle plataformaren inguruan duten ezagutza- eta erabilera-maila altua dela. Baina kasu honetan datu kuantitatiboak ez datoz bat datu kualitatiboekin. Horrenbestez, eztabaida taldean ikasleek adierazi dute platafor- 
man erabiltzen dituzten tresnen inguruan tutoreek duten ezagutza-maila altua dela, baina plataformaren beste hainbat tresnaren inguruan ez dutela inolako azalpenik jaso tutoreen aldetik. Bide horretatik, ikasleek uste dute erabiltzen ez diren tresnen inguruan tutoreek duten ezagutza-maila baxua dela.

Beraz, esan daiteke tutoreak ondo formatuak daudela plataforman erabiltzen diren tresnekin, baina plataformak eskaintzen dituen beste hainbat tresnen inguruan formazioa behar dutela, eta, ondoren, tresna berri hauek ikaste-prozesuan txertatu, ikasleei azaldu eta erabilera bultzatu behar dutela.

Irakasleek formazio sistematiko eta integrala behar dute plataforma digitaletan lan egiteko, baita Moodle plataforman ere (Islam, Onik eta Azad, 2013). Baina ez hori bakarrik, plataforman egin beharreko lanean, tutorearen bideratze lanak duen garrantzia nabarmen azaldu da ikerketan, beste azterlan batzuetan gertatu den bezala (Abdelraheem, 2012; Carvalho et al., 2011; Costa et al., 2012; Escobar eta Monge, 2012; Wahab et al., 2013; Wei Goh et al., 2013).

Islam eta Azad (2015) ere uste berekoak dira. Haien aburuz, Moodle eta antzeko plataformek ez dute berrikuntza pedagogikoa azaleratzen, baldin eta irakaslearen paperean ez bada funtsezko aldaketa bat gertatzen. Hori bat dator Sánchez Santamaría eta lankideek, (2012) diotenarekin, alegia, ezinbestekoa dela tutoreen rola ikasleen behar berrietara egokitzea, bitartekari eta gidari lanetan oinarrituta, tutoreen gidari rola ezinbestekoa delako era honetako plataforma digitalak klasean era eraginkorrean erabiltzeko.

\section{8. ondorioa: Ikasleak gustura daude Moodle plataformarekin .}

Ikasle gehienak oso gustura daude Moodle plataformarekin. Galdetegian gai honen inguruan galdetzerakoan emaitzen batez bestekoa 2,9koa izan da (0-4 eskalan). Eztabaida taldean jasotako ebidentziak ere ildo beretik doaz; taldeko kide guztiek adierazi dute plataforman lan egitea erraza dela, oso plataforma azkarra dela, eta material guztia eskura dagoela. Ebidentzia hauek bat datoz aztertutako ikerketa lanetan aurkitutako emaitzekin. Asko aipatzen da Moodle plataforman lan egitea oso erraza dela (Abdelraheem, 2012; Cejuela, Chinchilla, Blasco, Cortel eta Pérez, 2007; Costa et al., 2012; Grace Jun eta Lee, 2012; Islam, Onik eta Azad, 2013; Sánchez Santamaría et al., 2012; Poza, García, Gómez eta Hornero, 2011; Wei Goh et al., 2013).

Eztabaida taldean aipatu den beste gai bat plataformaren erabilerarena izan da. Ikasleen ustetan plataforma kasu gehienetan materialak jasotzeko bakarrik erabiltzen dute, hau da, eduki biltegi antzera. Errebisatu diren ikerketa lanetan baieztapen hau kontrastatzen da (Borwarnginn eta Tate, 2014; Carvalho et al., 2011; Cejuela et al., 2007; Costa et al., 2012; Sánchez Santamaría et al., 2012; Poza et al., 2011; Wei Goh et al., 2013). 
Bukatzeko, plataformaren inguruan aipatzen den beste gai bat plataformaren erabilera-maila izan da,ateratzen zaion etekin maila. Eztabaida taldeko kide guztiak bat datoz HUHEZIn Moodle plataformari ateratzen zaion etekina oso baxua dela. Uste dute plataforma askoz ere ahaltsuagoa dela eta hemen etekin gutxi ateratzen zaiola. Iglesias, Olmos, Torrecilla eta Mena (2014) bat datoz adierazpen hauekin. Aditu horien ustetan, klase presentzialetan Moodle plataformak eman dezakeen laguntza oso anitza da eta ahaleginak egin behar dira duen potentzia guztia ateratzeko. Bestela, soilik biltegi funtzioa beteko du, fitxategiak igo eta deskargatzeko funtzioa hain zuzen.

Beste ikerketa batzuekin sintonian dago azken ebidentzia hori (Costa et al., 2012; Islam, Onik eta Azad, 2013).

\section{GOMENDIO PRAKTIKOAK ETA ETORKIZUNEKO IKERKETARAKO GOMENDIOAK}

Foroaren erabilera materietan nolakoa izan behar den analizatu behar da. Ikerketa lan honetan lortutako emaitzak eta beste ikerlan batzuen berrikuspena kontuan izanda, komenigarria izan daiteke tresna honen erabilera bultzatzea. Komunikazio tresna baliagarria izateaz gain, materiaren inguruko zalantzak eta zalantzen erantzunak bertan gordetzeko aukera emango du. Eta bide batez, beste bi funtzio izango ditu bertan gordetako edukiak: ezagutza partekatzea ikasleen artean, eta elkarren arteko galde-erantzunekin ezagutza garatzen joatea.

Ikasleen ustetan oso baliogarria izan daiteke plataforman ikasketa guztiko lanak gordetzeko biltegi edo portfolio antzeko bat izatea. Horrek asko lagunduko du ikaslearen egunerokotasunean hainbat kontsulta egin ahal izateko eta material edo eduki guztiak leku bakarrean edukitzeko. Beraz, Moodle plataformak funtzio hori betetzen duen tresnarik ba al daukan begiratzea gomendatzen dugu, eta ondoren ikasle talde txiki batekin erabiltzen hastea proba guztiak egin arte. Bukaeran fakultate osoan zabaldu daiteke.

Plataformako edukien artean ikus-entzunezko material asko txertatzen dira. Gomendioa da zaintzea zein material txertatzen diren eta material horien erabilera gelan nolakoa den. Ikasleentzat edozein materialek ez du balio; beraien ustetan edukiek plus bat eskaini behar diote materiari, erakargarriak izan behar dira, motibagarriak. Bestalde, bideo luzeak eta oso estatikoen erabilera ekiditu behar da. Gai berdinaren inguruan, gomendagarria da tutoreek klasean ez erakustea zuzenean plataforman jarritako material berbera. Ikasleen arreta eta balorazioa asko jaisten da. Estrategia aproposak bilatu beharko dira plataforman txertatzen diren edukiak klasean era zuzenean erakusteko. 
Ikerketa lan hau egin ondoren, bide ugari eta oso interesgarriak planteatzen dira etorkizunean gehiago sakontzeko. Ikasleen pertzepzioa jaso da, baina zein da irakasleen pertzepzioa? Bat dator ikasleen pertzepzioarekin? Bide berriak irekitzen ditu? Irakasleen iritziak oso garrantzitsuak izan daitezke plataformaren diagnosia egiteko. Beste ikasle profil batzuekin lan honetako emaitzak konparatzea ere oso interesgarria izan daiteke. Zein iritzi dute graduko azken kurtsoko ikasleek? Bat datoz lehenengo mailako ikasleen iritziekin? Eta online ikasketetako ikasleek? Presentzialeko ikasleekin bat datoz?

Beraz, lan hau ez da hemen bukatzen. Moodle plataformaren diagnosi erreal bat egiteko HUHEZI fakultatean, ikerketa lan honi jarraipena eman behar zaio hemen aipatu diren galderei erantzunez.

\begin{abstract}
Currently online platforms play an important role in education and are being used in most universities. In the three degrees taught in classroom modality, in the Faculty of Humanities and Education (HUHEZI) of Mondragon Unibertsitatea, Moodle has been used since 2009-2010. So far there has been no assessment of the use of the platform in the three degrees. This research wants to analyze certain aspects of such use and aims to primarily, answer these questions: whether the teaching sequence defined in the design of the subject? in Moodle helps to better understand the organization of the subject; whether students know the Discussion Board tool of the platform and if they use it; and ultimately, what level of awareness tutors have as far as the platform is concerned and how much they use it. The results withdrawn from this analysis indicate that the teaching sequence of the subject defined in the platform helps most of the times to better understand the organization of the subject; the vast majority of students do not know or use the discussion board tool platform; similarly, although most students believe that tutors show, manifest, demonstrate, exhibit a high level of knowledge of the platform, they also claim that many tools available in Moodle are not used.
\end{abstract}

Keywords: Moodle, design, forum, perception, online, platform

En la actualidad las plataformas online tienen un papel muy importante en la educación y se están utilizando en la mayoría de 
las universidades. En los tres grados que se imparten en modalidad presencial, en la facultad de Humanidades y Ciencias de la Educación (HUHEZI) de Mondragon Unibertsitatea, se utiliza la plataforma Moodle desde el curso 2009-2010. Hasta ahora no se ha hecho ninguna evaluación acerca de la utilización de la plataforma en esos tres grados. Este trabajo de investigación quiere analizar ciertos aspectos de dicha utilización, en concreto se quiere responder a estas preguntas: La secuencia didáctica que se define en el diseño de la asignatura en Moodle, ayuda a entender mejor la organización de la asignatura? Los alumnos conocen la herramienta Foro de la plataforma? La utilizan? Cuál es el nivel de conocimiento y uso de la plataforma por parte de los tutores? A tenor de los resultados obtenidos, la secuencia didáctica de la asignatura definida en la plataforma ayuda en la mayoría de las veces a entender mejor la organización de la asignatura, los alumnos, en una amplia mayoría no conocen ni usan la herramienta Foro de la plataforma y aunque la mayoría de los alumnos creen que el nivel de conocimiento de la plataforma por parte de los tutores es alto, también creen que no se utilizan muchas herramientas disponibles en Moodle.

Palabras clave: Moodle, diseño, foro, percepción, online, plataforma

Actuellement les plateformes en ligne jouent un rôle important dans l'éducation et sont utilisés dans la plupart des universités. Dans les trois grades enseignées dans la modalité face-à-face, à la Faculté des Sciences Humaines et de l'Education (HUHEZI) de Mondragon Unibertsitatea, la plate-forme Moodle est utilisée depuis l'année scolaire 2009-2010. Jusqu'à présent, il n'y a pas eu d'évaluation à propos de l'utilisation de la plate-forme dans les trois grades. La recherche que nous présentons veut analyser certains aspects de cette utilisation, en particulier on veut répondre à ces questions: La séquence didactique qui est définie dans la conception du cours sur Moodle, nous permettra de mieux comprendre l'organisation de la matière? Les élèves connaissent-ils l'outil «Forum» de la plate-forme? L'utilisent-ils? Quel est le niveau de connaissance et d'utilisation de la plate-forme parmi les tuteurs du cours? Sur la base des résultats obtenus, la séquence didactique de la matière définie dans la plate-forme aide dans la majorité des cas afin de mieux comprendre l'organisation de la matière. La plupart des étudiants ne connaisse pas ou n'utilise pas l'outil de la plate-forme «Forum», et, bien que la majorité des étudiants pensent que le niveau de connaissance de la plate-forme parmi les tuteurs du cours est élevée, ils estiment quand-même que de nombreux outils disponibles dans Moodle ne s'utilisent pas.

Mots-clé: Moodle, conception, forum, perception, online, plateforme 


\section{ERREFERENTZIAK}

Abdelraheem, A. Y. (2012). Interactions Quality in Moodle as Perceived by Learners and Its Relation with Some Variables. Turkish Online Journal of Distance Education-TOJDE, 13(3), 375-389.

Adell, J., Castellet, J. eta Gumbau, J. (2004). Selección de un entorno virtual de enseñanza/aprendizaje de código fuente abierto para la Universitat Jaume I. http://cent.uji.es/doc/eveauji_es.pdf - 2014ko uztailaren 9an kontsultatua.

Álvarez, J.F. (2010). Estrategias para favorecer el aprendizaje eficaz con la plataforma Moodle del centro. http://es.slideshare.net/juanfratic/estrategias-para-favorecer-el-aprendizaje-eficaz-con-la-plataforma-moodle-del-centro-6591586 2014ko abenduaren 20an kontsultatua.

Borwarnginn, P. eta Tate, A. (2014). An investigation into students perceptions and lecturers perceptions of a virtual learning environment. http://www.aiai. ed.ac.uk/project/ix/documents/2014/2014-edulearn-borwarnginn-vle-survey. pdf 2014ko urriaren 24an kontsultatua.

Carvalho, A., Areal, N. eta Silva, J. (2011). Students perceptions of Blackboard and Moodle in a Portuguese university. British Journal of Educational Technology, 42(5), 824-841.

Cejuela, R., Chinchilla, J.J., Blasco, J.J., Cortell, J.M. eta Pérez, J.A. (2007). Evaluación de la plataforma Moodle, en la formación semipresencial, de entrenadores personales y deportivos. http://www.dgde.ua.es/congresotic/public_doc/ pdf/26133.pdf 2014ko azaroaren 2an kontsultatua.

Chen, D., Wang, Y. eta Hung, D. (2009). A journey on Refining Rules for Online Discussion: Implications for the desingn of Learning Management Systems. Journal of Interactive Learning Research, 20(2), 157-173.

Ciudad, A. (2010). Teaching innovation and use of the ICT in the teaching-learning process within the new framework of the EHEA, by jeans of Moodle platform. American Journal of Business Education, 3(13), 13-19.

Corbeil, J.R. eta Valdes-Corbeil, M.E. (2013). Faculty and student perceptions of their learning management sistem's social learning tools. http://tinyurl.com/ oxeap4s 2015eko urtarrilaren 10ean kontsultatua.

Correa, J.M. (2005). La integración de plataformas de e-learning en la docencia universitaria: Enseñanza, aprendizaje e investigación con Moodle en la formación inicial del profesorado. Revista Latinoamericana de Tecnología Educativa, 4(1), 37-48. Hemendik jasoa: http://www.unex.es/didáctica/RELATEC/ sumario_4_1.htm

Cosano, F. (2013). La plataforma de aprendizaje Moodle como instrumento para el Trabajo Social en el contexto del Espacio Europeo de Educación Superior. Acciones e investigaciones sociales, $1,367$.

Costa, C., Alvelos, H. eta Teixeira, L. (2012). The use of Moodle e-learning platform: a study in a Portuguese University. Procedia - Technology, 5, 334-343.

Dervin, B. eta Clark, K. (1987). Asking significant questions: Alternative tools for information need and accountability assessments. Belmont, CA: Peninsula Library System.

Elmahadi, I. eta Osman, I. (2012). E-Learning and e-technologies in Education (ICEEE), 2012 International Conference on, 158-161. 
Escobar, T. eta Monge, P. (2012). The acceptance of Moodle technology by business administration students. Computers and Education, 58, 1085-1093.

Grace Jun, H. eta Lee, H. (2012). Student and teacher trial and perceptions of an online ESL academic writing unit. Procedia - Social and Behavioral Sciences $34,128-131$.

Grau, G. (1995). Metodología para la validación de cuestionarios. Medifam, 5/6, 351-359.

Iglesias, A., Olmos, S., Torrecilla, E.M. eta Mena, J.J. (2014). Evaluar para optimizar el uso de la plataforma Moodle (STUDIUM) en el departamento de didáctica, organización y métodos de investigación. Tendencias Pedagógicas, $23,155-170$.

Islam, N. eta Azad, N. (2015). Satisfaction and continuance with a learning management system. The International Journal of Information and Learning Technology, 32(2), 109-123.

Islam, N., Onik, F. eta Azad, N. (2013). Comparing the post-adoption perceptions of educators and students with an e-learning platform. http://aisel.aisnet.org/ cgi/viewcontent.cgi?article=1227\&context=ecis2013_cr 2014ko Abenduaren 15ean kontsultatua.

López, J.M., Romero, E. eta Ropero, E. (2010). Utilización de Moodle para el desarrollo y evaluación de competencias en los alumnos. Formación Universitaria, 3(3), 45-52.

Marín, V. eta Maldonado, G. (2010). El alumnado universitario cordobés y la plataforma virtual Moodle. Pixel-Bit. Revista de Medios y Educación, 38, 121-128.

Martín, T. eta Serrano, A. (2009). The role of new technologies in the learning oricess: Moodle as a teaching tool in Physics. Computers and Education, 52, 34-44.

Martín Arribas, M.C. (2004). Diseño y validación de cuestionarios. Matronas profesión, 5(17), 23-29.

Maz, A., Bracho, R. , Jimenéz, N. eta Adamuz, N. (2012). El foro en la plataforma Moodle: un recurso de la participación cooperativa para el aprendizaje de las matemáticas. EDMETIC, Revista de Educación Mediática y TIC, 1(2), 29-43.

Moodle (2011). http://www.moodle.org/ - 2014ko Urriaren 10ean kontsultatua.

Muhsen, Z., Maaita, A., Odah, A. eta Nsour, A. (2013). Moodle and e-learning tools. I.J. Modern Education and Computer Science, 6, 1-8.

Muñoz, D.C., Ortiz, J.A. eta González, C. (2010). Evaluación de la plataforma Moodle en la enseñanza de un curso en el dominio médico. Revista Colombiana de Tecnologías de Avanzada, 16(2), 17-24.

Nikodijevic, A., Kuzmanovic, A. eta Ancelkovic, J. (2014). Students preferences towards e-learning environment. Education management 287 - Symorg 2014, 288-295.

Novo, I., Varela, L. eta Ramil, M. (2013). E-learning and face to face mixed methodology: Evaluating effectiveness of e-learning and perceived satisfaction for a microeconomic course using the Moodle platform. Computers in Human Behavior, 29, 410-415.

Ornat, C. eta Kallas, Z. (2012). Moodle, Web 2.0 \& «IFRAME». http://upcommons.upc.edu/bitstream/handle/2117/17752/Ornat\%20y\%20Kallas\%20 web\%202.0.pdf?sequence $=12014 \mathrm{ko}$ abenduaren $22 \mathrm{an}$ kontsultatua. 
Piotrowski, M. (2010). What is an e-learning platform?. In: Kats, Y. (2010). Learning management system technologies and software solutions for online teaching: tools and applications, (20-36). USA: Rivier College.

Poza, J., García, M., Gómez, C. eta Hornero, R. (2011). Implantación y evaluación de la plataforma Moodle en la docencia de la asignatura de Grado «Teoría de la Comunicación». II Jornadas sobre Innovación Docente y Adaptación al EEES en las Titulaciones Técnicas. Universidad de Valladolid.366-369.

Romero, C., Ventura, S. eta García, E. (2008). Data mining in course management systems: Moodle case study and tutorial. Computers and Education, 51, 368-384.

Sánchez Santamaría, J., Sánchez Antolín, P. eta Ramos, F.J. (2012). Usos pedagógicos de Moodle en la docencia universitaria desde la perspectiva de los estudiantes. Revista Iberoamericana de Educación, 60, 15-38.

Sánchez, J. eta Morales, S. (2012). Docencia universitaria con apoyo de entornos virtuales de aprendizaje (EVA). Digital Education Review, 21, 33-46.

Subramanian, P., Zainuddin, N., Alatawi, S., Javabdeh, T., Hussin, A. (2014). A study of comparison between Moodle and Blackboard based on case studies for better LMS. Journal of information systems research and innovation. http://seminar.utmspace.edu.my/jisri/ 2015eko otsailean kontsultatuta.

Wahab, R., Ali, F., Thomas, S. eta Al Basri, H. (2013). Students perceptions of Moodle at the CHS. 2013 Fourth International Conference on e-Learning «Best Practices in Management, Design and Development of e-Courses: Standars os Excellence and Creativity», 97-101.

Wei Goh, W., Lang Hong, J. eta Gunawan, W. (2013). Exploring students perceptions of learning management system: An empirical study based on TAM. 2013 IEEE International Conference on Teaching, Assesment and Learning for Engineering (TALE). 367-372.

$\mathrm{Xu}, \mathrm{Y}$. eta Yu, Y. (2004). An enhanced technology acceptance model for web-based learning. Journal of Information Systems Education, 15(4), 365-374. 